\title{
O Nunca Mais é a fera: ensaio sobre perda e predileção
}

Luciana Tiscoski

UFSC

\section{Resumo}

A partir da leitura (escuta) dos poemas reunidos em Cantares de perda e predileção, de Hilda Hilst (1930-2004), o seguinte artigo propõe uma retomada e subversão de temas e topoi poéticos encontrados em escritos de Sor Juana Ines de La Cruz (1651-1695) no poema Primero Sueño. As pistas são fornecidas pela própria Hilda Hilstquando insere nos Cantares a epígrafe com versos da monja mexicana. Percorrendo essa afinidade eletiva, revelam-se cisões e conflitos de opostos complementares na metáfora medieval da lírica trovadoresca em seus cantos ao amor inatingível. Hilda Hilst utiliza-se dos motivos dos trovadores para renovar a voz da linguagem na dura batalha do ódio-amor travada em torno do objeto inapreensível. Perda e luto são elementos poéticos inseridos na melancolia dos cantos, em que as teorias do fantasma de Eros fundem-se ao Narcisismo e ao desejo de conhecimento. O artigo tenta recompor o fluxo incondicional da poesia como ut pictura poesis, como pensamento imaginativo, pintura como diz Agamben "no sentido de que a poesia possui o seu objeto sem o conhecer, e de que a filosofia o conhece sem o possuir [...]”.

Palavras-chave: Hilda Hilst; Sor Juana Inés de La Cruz; voz; linguagem; imaginação.

\section{Résumé}

De la lecture (écoute) des poèmes réunis dans le Cantaresde perda e predileção, Hilda Hilst(1930-2004), l'article suivant propose une reprise et la subversion des sujets et des topoï poétique trouvés dans les écrits deSorJuana Inès de laCruz (1651-1695) dans le poème PrimeroSueño. Les chemins sont indiquées par Hilda Hilst, elle mémme, qui insére avant les poemes, l'épigraphe des vers et dela poète mexicaine. En passant parcette affinité élective, il y a des division set des conflits d'opposés complémentaires dans la métaphore de la lyrique des troubadours médiévaux dans leurs chantes à l'amour inaccessible. Hilda Hilst utilise les motifs des troubadours de renouveler le langage de la voix dans la dure bataille de l'amour-haine menée autour del'insaisissable de l'objet. Perte et deuilsont des éléments poétiques insérés dans la mélancolie des chantes, où les théories de le fantôme d’Eros sont fusionner au narcissisme et le désir de connaissance. L'article essaie de récupérer le flux inconditionnel de la poésie comme ut pictura poesis, comme pensée imaginative, la peinture comme dit Agamben «dans le sens que la poésie possè de son objet, sans le savoir, et que la philosophie connaît son objet sans le posséder[...]».

Mots-clés: HildaHilst; Sor Juana Inès de laCruz; voix; langage; imagination. 
1. AGAMBEN, Giorgio.

Estâncias - a palavra e o fantasma na cultura ocidental,2007, p. 14.
Después de todo, sería útil renunciar, en crítica literaria, a la aburrida sucesión diacrónica $y$ volver al sentido original de la palabra texto - tejido - considerando todo lo escrito y por escribir como un solo y único texto simultáneo en el que se inserta ese discurso que comenzamos al nascer. Texto que se repite, que se cita sin límites, que se plagia a sí mismo; tapiz que se desteje para hilar otros signos, estroma que varía al infinito sus motivos y cuyo único sentido es ese entrecruzamiento, esa trama que el lenguaje urde. Severo Zarduy, 1969

Os Cantares de Hilda Hilst (1930-2004) anunciam, desde seu título, a escolha efetuada pela poeta quando apela ao inapreensível da poesia, como o canto pode sê-lo nos poemas escritos. A linguagem da voz poética que ressoa nesses cantos aqui referidos encontra-se com a voz da linguagem da tradição oral e musical da poesia lírica das trovas galego-portuguesas e dolce-stil-novistas. O amante predileto é cantado sob o signo da perda. O canto ao amor é celebração ao dispêndio, quando a linguagem revela um "entrebescamen textual de fantasma”, uma busca de conhecimento sem utilidade que leva a infinitos desdobramentos. É a relação fantasmática de uma antiga tradição oral da festa e da celebração, de antes ainda, nas elegias e odes, além da melancolia barroca, que aparece nas páginas dos cantos de Hilda Hilst. A leitura de Giorgio Agamben em Estâncias - a palavra e o fantasma na cultura ocidental mostra-nos a pervivência da teoria do fantasma na elaboração da poesia moderna ocidental. Segundo Agamben,

a teoria do fantasma está subentendida no projeto poético
que a lírica-trovadoesca-estilo-novista deixou em herança
para a cultura europeia e na qual, através do denso en-
trebescamen textual de fantasma, desejo e palavra, a poesia
construía a própria autoridade, convertendo-se ela mesma
na "estância" oferecida à gioichemai non fina [alegria que
nunca acaba] da experiência amorosa. ${ }^{1}$

Os cantos de Hilda Hilst apresentam-se entretecidos, em tramas, fios retorcidos, armadilhas, que impedem a aproximação do poeta de seu objeto de desejo, como da voz à linguagem, 
do espírito ao conhecimento. Trata-se de um emaranhamento que excede a trama dos objetos e vai se tecendo no tempo e no texto, "o trabalho de Penélope da reminiscência"2, ou do esquecimento, como diria Walter Benjamin de Marcel Proust. O tempo fugidio, sumidiço e irrecuperável mostra-se sob a lei do esquecimento. Os gestos nulos, o tecer da memória nos calendários, nos negativos em preto e branco, os fatos, as fitas e fotos em "rolo sinistroso nas gavetas" não impedem o "tempo de estancar o jorro de umas vidas" . O tempo da experiência amorosa, da "luz da caridade", "Do ouro. Do vermelho das carícias.”, dá espaço à dor e ao afastamento. Alegoricamente cantado nos poemas, como a mulher-trovador que busca o amante ou amigo, Hilda Hilst revela os abismos que cindem os "fatos roídos" e a "carnação da vida”. Por traz da alegoria do jogo e da caça mulher-trovador e amante/amigo, a referência poética das cantigas é exaltação da voz, onde o corpo exerce o canto na dança e na festa, antes das palavras e da escrita, o corpo fala.

Hilda Hilst elabora um pensamento em torno dessas passagens, um pensamento poético que se expõe dilacerado entre os rumores desses fantasmas, dos mitos e saberes,em que religião, misticismo, matemática e ciência traçavam figurações do universo, em círculos, elipses, espirais, de Galileu a Kepler, na tentativa de apreender a vida e a morte.Para Hilda Hilst, "a procura da voz na linguagem é o pensamento" 4 . No entanto, o pensamento se quer canto, quer se antecipar na linguagem, e exercer a voz no corpo, como potência vocal, quando transposto à poesia. Outra passagem, outra travessia.

Eduardo Sterzi cita Paul Zumthor e sua desconfiança com a palavra literatura (do latim littera - letra) ao tratar manifestações poéticas medievais, pois

todo texto poético ou ficcional, dos séculos IX e X até pelo menos o XIV, transitou pela voz, e este trânsito não foi aleatório. Mesmo composto por escrito e na paz de alguma cela, o texto comporta, inscrita nas suas profundezas, uma intervenção determinante, que age sobre ele como um poderoso fator de formalização: a intenção de se dizer [l'intention de se dire], quero dizer, de desabrochar [s'épanouir] num ato vocal. ${ }^{5}$

Sterzi chega mesmo a afirmar "que o típico poema lírico moderno é sempre uma espécie de alegoria formal da passagem da poesia musical-vocal para a poesia escrita”, sendo, portanto, inerente à poesia uma tensão constante entre o código musical e o código gráfico, ou entre a voz e a linguagem.Nessa perspectiva, pode-se afirmar que numa conjuração dos fantasmas, a modernidade propõe "uma retomada, perspectivação e superação da experiência lírica”? É o que alega Sterzi aludindo a
2. BENJAMIN, Walter. A imagem de Proust. In: Magia e técnica, arte e política. Obras escolhidas volume I. 1994, p. 37.

3. HILST, Hilda. Cantares de perda e predileção. Canto II, 1983.

4. AGAMBEN, Giorgio. O fim do pensamento.

5. ZUMTHOR (1993) apud STERZI (2012),Da voz à letra, p. 2012, p. 67. 
6. HILST, Hilda. Cantares de perda e predileção. Canto XXXIII, 1983.

7. (praedilectione, do latim prae - diante de, e dilectione amor, preferência).

8. Hoje o Instituto Hilda Hilst - Centro de Estudos Casa do Sol recebe estudantes e artistas que se dedicam a pesquisas em suas bibliotecas ou realizam manifestações artísticas na casa. O escritor espanhol José Luis Mora Fuentes faleceu em junho de 2009. Ficaram responsáveis pelo Instituto Hilda Hilst sua esposa, a artista plástica Olga Bilenky, e o filho de ambos, Daniel Bilenky Mora Fuentes, herdeiro legal dos direitos autorais da escritora Hilda Hilst.

9. Apesar da profunda identificação que se pode evidenciar entre a personagem protagonista de $A$ obscena Senhora $D$ e sua criadora, seria ainda assim leviano declarar a obra como autobiográfica, não fosse uma anotação pessoal, datada de 22 de janeiro de 1980, em que H. H. escreve: "Muita felicidade. Não quero morrer. Não vou mais morrer. Senhora D/HH está viva.”, numa clara referência ao traço autobiográfico da obra.

Portal Cultural Hilda Hilst -

$O$ Vermelho da Vida. Disponível em: http://www.hildahilst. com.br.cpweb0022.servidorwebfacil.com/obras.php?catego$\mathrm{ria}=8 \& \mathrm{id}=63$. Acesso em $22 \mathrm{de}$ janeiro de 2008.

10. A fragmentação do eu moderno de Hilda Hilst é percebida em sua face bipartida na prosa-poema/proema e na poesia. O sentido, os pensamentos recônditos e as conclusões lógicas e fatídicas do encadeamento poético da prosa hilstiana, por sua densa carga filosófica, conduzem à inexorabilidade da morte. Já, na poesia, a própria forma do
Mallarmé e à experiência de Un coup de dés bem como, antes de Mallarmé, a Dante com Vita Nova. A modernidade é muito vasta, assim como a experiência lírica. Neste ensaio, interessa colocar essa retomada, perspectivação e subversão da experiência lírica, como tentativa intrínseca aos cantos de Hilda Hilst. E, conforme as palavras de Sterzi sobre a lírica moderna, a poeta também se enamora (inutilmente) pela música e pela voz e, fazendo-se investigação e reflexão, pelo silêncio.

\section{XXXIII}

Se te pronuncio

Retomo um Paraíso

Onde a luz se faz dor

E gelo a claridade.

Se te pronuncio

É esplendor a treva

$\mathrm{E}$ as sombras ao redor

São turquesas e sóis

Depois de um mar de perdas.

Vigio

Esta sonoridade dos avessos.

Que se desfaça o fascínio do poema

Que eu seja Esquecimento

E emudeça. ${ }^{6}$

Cantares de Perda e Predileção ${ }^{7}$ foiescrito na residência da autora em Campinas, a chamada Casa do Sol, entre os anos de 1981 e 1982, e publicado em 83. Com uma tiragem de mil exemplares pela Editora de Massao Ohno, a capa traz a reprodução de uma mandala sobre papel com nanquim e aquarela, da artista plástica Olga Bilenky, esposa do escritor José Luís Mora Fuentes, ambos grandes amigos de Hilda Hilst e mantenedores do projeto da escritora de transformar sua residência num espaço de pesquisa, intercâmbios e demais eventos culturais e artísticos ${ }^{8}$. Em 2001, sob a organização de Alcir Pécora, a Editora Globo relançou a obra completa de Hilda Hilst com a publicação de seus escritos em poesia, prosa, dramaturgia e crônicas, tendo, no plano de edição, optado por reunir os dois Cantares -Cantares de perda e predileção, de 1983, e Cantares do sem nome e de partidas, de 1995 -última publicação poética inédita de Hilda Hilst - em um único livro, sob o título Cantares, em 2004.

O texto eleito paradar largada às publicações da Editora Globo foi $A$ obscena Senhora $D^{9}$, um dos livros em prosa poética $^{10}$ da escritora paulista, finalizado em 1981, publicado originalmente em 1982 por Massao Ohno - Roswitha Kempf Editores. Três meses após finalizar este livro, H.H. inicia a escrita deCantares de perda e predileção, embora a feitura 
desses cantares já estivesse sendo elaborada anteriormente, pois A obscena senhora $D$ traz na primeira página o poema $\mathrm{XV}$ dos Cantares, transcrito abaixo.

Para poder morrer

Guardo insultos e agulhas

Entre as sedas do luto.

Para poder morrer

Desarmo as armadilhas

Me estendo entre as paredes

Derruídas.

Para poder morrer

Visto as cambrais

E apascento os olhos

Para novas vidas.

Para poder morrer apetecida

Me cubro de promessas

Da memória.

Porque assim é preciso

Para que tu vivas. ${ }^{11}$

O signo da perda e do luto já estava também no título desse livro, na letra D.

D de derrelição, ouviu? Desamparo, Abandono, desde sempre a alma em vaziez, buscava nomes, tateava cantos, vincos, acariciava dobras, quem sabe nos frisos, nos fios, nas torçuras, no fundo das calças, nos nós, nos visíveis cotidianos, no ínfimo absurdo, nos mínimos, um dia a luz, o entender de nós o destino [...]..$^{12}$

Insiste a personagem narradora, Hillé, a Senhora D, nos porquês e nos "luxos do pensamento", o texto é tecido e retorcido, buscando nomes e tateando cantos. Derrelição remete à res delicta, expressão latina que designa a "coisa abandonada", o que juridicamente compreende "abandono voluntário de coisa móvel, com a intenção de não mais a ter para si”, como lembrado por Caio Fernando Abreu, escritor gaúcho e amigo de H.H., quando escreve a apresentação de seu livro. A perda, o abandono, a derreliçãosão expostos numa tensão que se apresenta na linguagem da voz, na medida em que se trata de uma linguagem com corpo, que tateia, acaricia, em "dobras, frisos, vincos, no fundo das calças”, e busca um entendimento ainda (e sempre) inapreensível. Segundo Caio Fernando Abreu, a linguagem que ressoa da obscena senhora $D$ adquire voz em "sons, trinados, gritos, urros, rouquidões. Asa.", uma voz onde "as palavras ofegam e palpitam, como se tivessem carne, sangue, músculos, nervos, ossos." 13 encadear-se permitindo a quebra do verso, o enjambement, faz com que o sentido se afaste e se perca, restando,em vez do sentido, sentidos, em vez da profusão de vozes, o logos que cede espaço à phoné, ao canto e a ele se articula numa relação de jogo ou caça. Este recuo percebido na poesia é, no caso dos textos de Hilda Hilst, muito tênue, justamente por percebermos a dicção poética também em sua obra chamada prosa. Ainda assim, o recuo é identificável, questão levantada pela própria autora quando fala de sua predileção, na prosa, por autores contemporâneos como Joyce e Beckett e, na poesia, por Catulo ou Jorge de Lima, o qual, embora contemporâneo, não se coaduna exclusivamente a movimentos literários que possam relacioná-lo lado a lado a unanimidades do gosto popular, como Drummond, ou do gosto intelectual, como Haroldo de Campos. A autora declara a curiosa afinidade com uma "linha mais recuada da poesia e mais moderna da prosa" (A declaração pode ser lida na entrevista concedida aos Cadernos de Literatura Brasileira - Hilda Hilst, do Instituto Moreira Salles, Número 8, 1999, p. 39), o que pode ser constatado com a ressalva permanente de sua linguagem sempre mais próxima à poiésis, o fazer poético.

11.HILST, Hilda. A obscena senhora D.1982.

12. Idem.

13. ABREU, Caio Fernando. Apresentação: $A$ obscena senhora $D ., 1982$. A proximidade de Caio Fernando Abreu com Hilda Hilst e seu trabalho permitem que o escritor remeta à inventividade da linguagem exposta no proema de $A$ obscena senhora $D$, pois a compara, nesse mesmo texto,com escritores como os brasileiros Guimarães Rosa e Clarice Lispector e os irlandeses James Joyce e Samuel Beckett. 
14.BECKER, Ernest. A negação da morte. 1995, p. 16.

15.SARDUY, Severo. Escritos sobre um cuerpo, 1999, p. 1133.
A obscena Senhora $D$, uma espécie de autobiografia ficcional (embora acredite que toda autobiografia o seja),apresenta Hillé (a Senhora D) vivendo no vão de uma escada da própria casa (abaixo, portanto, da possibilidade de ascese e entendimento/conhecimento), onde se refugiou logo após a morte do marido, Ehud, seu interlocutor e duplo. A dedicatória do livro a Ernest Becker (1924-1974)traz o seguinte depoimento da autora: "Dedico este trabalho assim como o anterior, Da morte. Odes mínimas, e também meus trabalhosfuturos (se os houver) à memória de ErnestBecker por quem sinto incontida veementeapaixonada admiração. H.H.” (HILST, 1982). O homenageado é um antropólogo cultural estadunidense, autor do livro $A$ negação da morte, Prêmio Pulitzer 1974, um ensaio filosófico e psicanalítico que reúne diversas correntes da psicanálise pós-freudiana numa fusão da psicologia - em grande parte alicerçada pela obra de Otto Rank - com a perspectiva mítico-religiosa, tendo como principal guia o teólogo e filósofo dinamarquês Sören Kierkegaard. O livro de Becker, publicado em 1973, foi referência importante no pensamento e na formação filosófica da autora Hilda Hilst, tendo sido indicado pela própria a amigos aos quais ela presenteava com exemplares.

Em $A$ negação da morte, Ernest Becker relaciona a ânsia do homem pelo heroísmo com a ideia de narcisismo, de Freud. De acordo com Freud, os homensrepetem o mito grego de Narciso à medidaque se perdem em si mesmosnuma profunda absorção, esquecendo-se de, ou mesmo ignorando, suaprópria falibilidade. Becker faz a leitura da teoria de Freud afirmandoque "o inconsciente não conhece a morte ou o tempo: nos seus recessosorgânicos fisioquímicos mais íntimos, o homem se sente imortal"14. No entanto, para Becker epara Hilst, esse heroísmo cósmico almejado mostra o reflexo de sua verdadeiraface: o terror da morte. Em desafio à morte, Hilda projeta-se no tempode amanhã, na paisagem-limite, no extremo. Com sua poesia, a poetadeseja a transcendência.Eis que seu interlocutor é muitas vezes seu próprio reflexo, como a interlocução com Deus: um jogo de espelhos. A inventividade da linguagem hilstiana, no afã de uma criação que se elabore como imagem e reflexo, traz em si uma fonte de prazer erótico na medida em que se retroalimenta no deleite de sua própria alma. Severo Sarduy enfatizava que "tratar del sujeto es tratar del lenguaje, es decir, pensar la relación o coincidencia de ambos, saber que el espacio de uno es el del otro, [...] que éste [a linguagem] o constituye, o si se quiere, que ambos son ilusorios." ${ }^{15}$ 
16.HILST, Hilda. Cantares de

Me vias

Partida ao meio.

A cara das emboscadas

Dizias

Essa era a cara do meu desejo.

E possuías

O inteiriço, o Narciso

Tu mesmo e tua fantasia.

Um fronteiriço de linhas

Que se pensavam contíguas. ${ }^{16}$

perda e predileção. Duas estrofes do Canto V, 1983.

17.BROWN, Norman O.

Vida contra Morte: $\mathrm{O}$ sentido psicanalítico da História. 1974, p. 70.

18. AGAMBEN, Giorgio. Eros ao espelho. In: Estâncias: a palavra e o fantasma na cultura ocidental. 2007, pp. 144, 145.

Norman O. Brown (1913-2002), autor de Life Against Death: The Psychoanalytical Meaning of History (Vida contra Morte: O sentido psicanalítico da História), de 1959, e largamente citado por Becker, faz a seguinte leitura do narcisismo e suas proporções com a libido objetal em Freud, evocando imagens e pensamentos outros, como dos alemães Jakob Boëhme (1575-1624) e Friedrich Nietzsche (1844-1900):

Pode-se perceber o pensamento de Freud inibido por uma concepção de Eu e Outro como alternativas mutuamente exclusivas. A imagem de Narciso no mito e na poesia aponta outra direção: Narciso precisa de um lago, um espelho no qual se contemple. E, no misticismo de Boehme, a psicogênese da Criação é a necessidade que tem Deus de 'auto-reflexão' (Selbstabbildung) e de um espelho (Spiegel) no qual se veja. Nesse sentido o narcisismo de Freud teria a necessidade do Outro mais profundamente alicerçada: narcisismo, como Narciso, seria uma fonte de prazer e exuberância erótica. O Zarathustra de Nietzsche diz: "amo aquele cuja alma é superabundante de modo que se esquece de si mesmo e de todas as coisas que estão nele"; e também, "sua palavra pronunciava bem-aventurado o amor-próprio, o puro e saudável amor-próprio que jorra de uma poderosa alma - de uma poderosa alma a que pertence o corpo superior, belo, triunfante, repousante, em torno do qual tudo se transforma num espelho - o flexível, persuasivo corpo, o dançarino cuja parábola e epítome é a alma autodeleitosa." ${ }^{17}$

Agamben vê refletido nesse espelho, a partir de Averróis, não apenas "a forma do objeto", mas também a fantasia que “imagina os fantasmas na ausência do objeto.” E nesse sentido, "amar é necessariamente uma especulação". Conforme Agamben, outra das heranças legadas à cultura ocidental pela psicologia medieval é a concepção do "amor como um processo essencialmente fantasmático, que implica imaginação e memória, em uma assídua raiva em torno de uma imagem pintada ou refletida no íntimo do homem” ${ }^{18}$ Narciso então não se enamora de si, mas de uma imagem, sua "intenção erótica" 
19. BARTHES, Roland. $O$ prazer do texto. Lisboa: Edições 70, 1974, p. 49.

20.HILST, Hilda. Cantares de perda e predileção. Versos dos cantos X, XI, XIII, XIV, XVII, XIX, 1983.

21.FRÓES, Elson. Outros corvos. , 2000, p. 11. está sempre voltada para uma imagem. Encontram-se, na fonte do amor, Narciso e Eros.

O tempo que não existe é o tempo da poesia, mas que dilacera o corpo em direção à morte, é exposto e desafiado no texto de prazer e fruição dos cantos de Hilda Hilst. Anacrônica, clivada, duplamente perversa, sua poesia é "vontade de fruição", "faz vacilar as bases históricas, culturais, psicológicas, do leitor, a consistência dos seus gostos, dos seus valores e das suas recordações, faz entrar em crise a sua relação com a linguagem"19. A linguagem excede limites quando se aventura pelo canto que elabora um caminho do indizível, onde o heroísmo cósmico apreende imagens da memória e recolhe fragmentos na fantasia, no fantasma, que não reconhece tempo ou morte. O abismo que permanece em vida separando corpo e espírito, linguagem e voz, é ultrapassado pela poeta no seu canto. Se no proema da obscena Senhora $D$, esse abismo se coloca intransponível e a morte é o interlocutor mais evidente da narradora, a vida espelha-se na morte e rompe barreiras na poesia. Para poder morrer, é necessário que a poesia viva."Cara a cara (espelho e faca)", as "duplas fomes" de um mesmo corpo, a mesma "marcha de dois caminhos", "um corpo e duas batalhas", "Dois tigres / Colados de um só deleite", a poeta mulher-trovador aventura-se "No papel adentro" e procura "[...] a palavra / Companheira do grito." O espelhamento do "Corpo de carne / Sobre um corpo de água”, é fruição de um rio "E vive o percurso / Do que corre / Jamais chegando ao fim." ${ }^{20}$

\section{O corvo Nunca Mais}

A voz do corvo anunciando a morte é afastada nos Cantares. A voz animal da morte em Nevermore é transferida ao rugido da fera, o tigre que a poeta traz no flanco. A referência a The Raven, de Edgar Allan Poe, é invertida nos cantos de Hilda Hilst. A ave agourenta que anuncia o Nunca Mais é enfrentada pela simetria do tigre. Elson Fróes, em sua análise do poema de Poe, intitulada Outros corvos, apresenta o autor de $O$ corvo como responsável pela "desmistificação do poeta" e "desaurificação do poema"na poesia moderna, referindo-se ao texto Filosofia da Composição, no qual Poe apresenta o poeta não mais como "o vate inspirado 'picado por estro', mas como o fabbro com engenho e arte." ${ }^{21}$ Sabe-se da profunda antipatia que a escritora Hilda Hilst creditava a especulações que desmentissem o caráter eidético da poesia, questão esta que acabou por polarizar sua relação com a obra de João Cabral de Melo Neto, por exemplo. Mas não cabe aqui o julgamento 
dessas polarizações. Antes domodus operandi do poema, o que interessa, na verdade, é o grasnar do corvo de Poe na repetição de seu Nevermore, numa alusão à "mais legítima das tonalidades poéticas: a melancolia" 22 . Na problemática do poema de Poe, um corvo, com sua voz, foi capaz de representar o som da melancolia, o som da morte no grasnado Nevermore. E o aspecto mais melancólico é a morte da amada Lenore, que figura como agouro de um Nunca Mais. Apesar da originalidade e engenhosidade rítmica e métrica do poema, destacada pelo próprio poeta $^{23}$, a questão da tonalidade e sonoridade das palavras nas estâncias e o eco insistente e monótono do corvo é o que parece ressoar como o que determinou a vida longa e próspera de The Raven na admiração de poetas os mais diversos, incluindo os trabalhos de tradução do poema realizados por Mallarmé, Baudelaire, Fernando Pessoa e Machado de Assis, além da análise apurada de Roman Jacobson, que Haroldo de Campos destaca em seu texto de 1971,Edgar Allan Poe: uma engenharia de avessos.

Evidentemente não se pretende a análise nem de um verso do enigmático poema de Poe. No entanto, em Cantares,o Nunca Maisé por demais evidenciado como signo da perda, da melancolia e do lutopara que seja ignorado. Insere-se então na face barroca dos poemas uma presença em sombras e opostos que também não pode deixar de ser nominada: a melancolia barroca.

No canto XXVI de seus Cantares, apresenta-se uma mulher-trovador. Um certo "Descuidado" é o interlocutor da mulher-trovador, que se lamenta por sua criação de "palavras altas”, "montanhas de mágoas" e "venenoso lago". O canto é oúnico destino da garganta, o corpo guia a voz na linguagem, e dele se separa, ficando apenas a voz e seu eco. No corpo, o sacrifício da cruz. "Que simetria, justeza / Para ferir-me a mim / Como se a cruz quisesse / De mim ser a moradia.” No entanto, o trovador insiste: "E eu canto / Porque é esse o destino / Da minha garganta / E canto // coloquei duas barras porque há separação de estrofe, posso estar errada... Porque criança aprendi / Nas feiras: ave e mulher / Cantam melhor na cegueira." Existe um conflito muito evidente na relação de um corpo que canta uma linguagem que se faz em pensamento, reflexão, espelhamento. Um conflito entre palavra poética e palavra pensante adere-se aos conflitos de ódio-amor, aos contrastes, aos opostos, ao alto e baixo. A perda e a inapreensibilidade do objeto de desejo são transferidas ao conhecimento nunca saciado e à consequente incapacidade de representá-lo com a linguagem. Giorgio Agamben, ao lançar a pergunta "Sobre o que se recolhe tão tenazmente o seu trobar?”, referindo-se aos poetas do século XIII e à tradição lírica trovadoresca, propõe ele mesmo a resposta:
22.POE, Edgar Allan. The Philosophy of Composition. , 2000, p. 49. No original, em inglês: "Melancholy is thus the most legitimate of all the poetical tones".

23.Poe escreve sobre The raven, sem falsa modéstia: "Não me iludo, é evidente que haja originalidade tanto no ritmo quanto no metro de O Corvo. O primeiro é trocaico, o segundo é octâmetro acatalético, alternando com heptâmetro catalético repetido no refrão do quinto verso, terminando como tetrâmetro catalético", etc., etc., etc. E conclui: "Considerados isoladamente, cada um desses tipos de versos sem dúvida já vem sendo empregado através dos tempos; a originalidade de O Corvo reside na combinação deles no interior da estância.

Nada que se aproxime dessa combinação, mesmo de maneira remota, foi jamais tentado anteriormente. E o efeito desta originalidade de combinação se valeu da ajuda de outros efeitos incomuns, sendo alguns deles inteiramente novos, surgidos de uma expansão da aplicação dos princípios de rima e aliteração". POE, Edgar Allan. Filosofia da Composição, 2000, p. 72. 
Trata-se da cisão entre poesia e filosofia, entre palavra poética e palavra pensante, e pertence tão originalmente à nossa tradição cultural que já no seu tempo Platão podia declará-la "uma velha inimizade". De acordo com uma concepção que está só implicitamente contida na crítica platônica da poesia, mas que na idade moderna adquiriu um caráter hegemônico, a cisão da palavra é interpretada no sentido de que a poesia possui o seu objeto sem o conhecer, e de que a filosofia o conhece sem o possuir. A palavra ocidental está, assim, dividida entre uma palavra que tem para si toda a seriedade e toda a consciência, mas que não goza do seu objeto porque não o consegue representar (AGAMBEN, Estâncias, 2007, p. 12).

Cantares de perda e predileção foi também dedicado "à memória” do já citado Ernest Becker, no entanto, nos cantos, a questão da morte é colocada num outro diapasão, a morte é tratada como o grasnar longínquo do Nunca Mais, o corvo de Poe. A poeta afasta o pássaro que anuncia amorte, afasta a perda, o agouro, numa relação que se expressa como caça erótica, no roteiro de ódio-amor, luz e sombra.

\section{Sor Juana Inés de La Cruz}

Na epígrafe dos Cantaresde Hilda Hilst, a poeta e estudiosa de teologia da Nueva España, Sor Juana Inés de La Cruz (16511695), deixa o marco do embate entre o coração e o pneuma em versos que também remetem à perda e à predileção. De Sor Juana,Hilda Hilst tomou emprestadas as palavras sobre o amor e oconhecimento para a epígrafe de Cantares de perda e predileção:"... en líquido humor viste y tocaste / mi corazón deshecho entre sus manos" (versos do poema En que satisface un recelo con la retórica del llanto). Logo abaixo, outro verso da mesma poeta mexicana barroca: "A mí, no el saber (que aún no sé) / solo el desear saber me ha costado gran trabajo" (do texto Respuesta a Sor Filotea). Cumpre enfatizar aqui o desejo de saber como elaboração do pensamento poético, não como culto à tradição de um passado absoluto. As seguintes palavras de Maria Zambrano farão melhor essa diferenciação ou a distância entre saber e pensar:

Si el saber fuese lo adecuado a la condición humana, el hombre hubiera podido permanecer en las culturas de sabiduría, en algunas de las cuales se supo mucho de lo que ahora descubrimos, mucho quizá de lo que está al descubrirse. Mas si el saber es el imán del pensamiento, una vez logrado se acumula y se alza como pasado frente 
al hombre. Mientras que el pensar es acción, insustituible acción, en la que se revela la esencia de la condición humana; descubrir la ignorancia rescatando su libertad. Y sóloasí se abre el futuro. ${ }^{24}$

A epígrafe de Cantares de perda e predileção anuncia um barroco que se configura com as inseparáveis dobras do conhecimento, do desejo e do erotismo, mas atual e subversivo, anuncia também um anacronismo urgente, como tópos do contemporâneo, que se abre ao futuro. Octavio Paz reafirma a modernidade na poesia da monja mexicana quando escreve sobre o poema "más personal de Sor Juana".

Primero sueño es irreductible a la estética de su tiempo. O sea: a la poesía del desengaño. Lo mismo sucede, por lo demás, con todos los grandes poetas: expresan a su época y, simultáneamente, la niegan, son su excepción, aquello que de alguna manera escapa a la tiranía de los estilos, los gustos y los cánones. ${ }^{25}$

Poema barroco que nega o barroco, como referido por Paz, a poesia de Sor Juana é signo de um tempo. Signo também da melancolia, pois traz a marca do objeto de gozo inalcançável, como bem observa Haroldo de Campos em ensaio sobre amonja, em que alude à teoria do fantasma erótico de Agamben e à biografia de Sor Juana pelo também poeta mexicano Octavio Paz.

Trata-se de uma bela e amaríssima contribuição ao "tema do fantasma erótico", recorrente na literatura ocidental, como observa Paz, aludindo a uma tese de Giorgio Agamben. Em Stanze (1977) o ensaísta italiano desenvolve uma "teoria do fantasma", inscrita no "projeto poético" que remonta à lírica "trobadoresco-estilnovista". Agamben assinala que a "prática fantasmática", aliada à "negação do mundo exterior", efeito do narcisismo melancólico, abre um espaço intermediário, um "lugar epifânico". É onde se aloja "o objeto irreal da introjeção melancólica". A topologia assim desenhada culmina numa "epifania dell'inafferràbile” (do objeto de gozo inalcançável). ${ }^{26}$

O fantasma erótico do barroco é tópos também nos Cantares de Hilda Hilst que, além da afinidade eletiva com Sor Juana, revelam ainda matizes dos Cantares Bíblicos, o Cântico dos cânticos (Shir Hashirim). O poema do Antigo Testamento que traz a invocação do Rei Salomãoao amor de uma pastora sulamita (malgrado toda a extensa explicação dos padres da igreja que substituem os protagonistas do poema por Cristo e o povo de Israel, a Igreja e os fiéis, a união mística da alma com Deus ${ }^{27}$, etc.) é inteiramente percorrido por imagens e motivos eróticos. As vozes do coro, da sulamita e a voz do amado
24. ZAMBRANO, Maria. Dos fragmentos acerca del pensar., 1956, p. 5.

25. PAZ, Octavio. Primero sueño. In: Sor Juana Inés de La Cruz o Las Trampas de la Fe. 1985, p. 500.

26.CAMPOS, Haroldo.

Quotuor para Sor Juana. In: $O$ segundo arco-íris branco. 2010, p. 47.

27.A união da alma mística com o Divino numa dimensão erótica é a escolha feita pelo poeta místico espanhol San Juan de La Cruz, que no século XVI escreve o Cântico Espiritual, em referência ao Cântico dos Cânticos Bíblico. 
28.HILST, Hilda. Cantares de perda e predileção. Canto XXXVII, 1983. pastor (que completa o triângulo amoroso com Salomão e a sulamita) são celebradas ao longo do poema com insistência, como instrumentos e anúncio do jogo de sedução "o tempo do cantar chega", "faz-me ouvir a tua voz, porque a tua voz é doce”, "teu falar é doce”, "O seu falar é muitíssimo suave”. Nas vozes do poema cantado, o erotismo das lisonjas de Salomão aos pés e ao contorno das coxas da sulamita, "O teu umbigo, como sendo uma taça redonda", "O teu ventre como sendo um montão de trigo, cercado de lírios", "Seios semelhantes aos cachos de uvas”, etc., é tão abundante quanto o elogio à voz. Como lugar comum, a cidade e o campo, a caça e os animais que a representam. E o mesmo objeto de desejo inalcançável. De qualquer maneira, ainda que pertinente, os cantares bíblicos revelam outras possibilidades de leitura dos cantares de Hilda Hilst. Não há intenção de percorrê-las neste momento. Mas é importante que não se perca de vista a verve religiosa do erotismo poético que se espelha nos cantares como reflexo de um desejo de ascese aos avessos, como retomada de um tempo irrecuperável, de um tempo do cantar como transgressão, ódio formoso, porque revestido de canto e de poesia, de perda e predileção.

\section{XXXVII}

Quem é que ousa cantar, senhor, Um ódio dito formoso?

Que raro fosso há de ser $\mathrm{O}$ escuro melodioso

Esse tão meu, de sementes

De verdes dentro de um poço?

Que largueza incongruente

Nos versos, sem parecer

Que quem trova

Se fez demente.

Que altas novas

Este cantar de mulher:

Um ódio-fêmea, senhor,

É bem o fosso onde cresce a rosa:

A rara. De ódio-formoso. ${ }^{28}$

O ritual da caça se faz nos cânticos de Salomão e nos cantos de Hilda Hilst, num recorrente jogo de espelhamento, de aproximação e fuga, desejo e fracasso. $\mathrm{O}$ dualismo percorre os versos dos 70 cantos dos Cantares da poeta Hilda Hilstcom desdobramentos, como amore fúria, amor e cólera, branco 
e negro, que apresentam as metáforasde sua poesia, feita no "exercício de virtude e treva". O interlocutor como o trovador se espelham e se escondem no ritual de caça. $\mathrm{O}$ interlocutor é o amado, é Deus: “o arquiteto dessas armadilhas", e é o próprio poeta trovador. $\mathrm{O}$ dualismo trazainda em essência a representação do corpo e do espírito emconvivência e luta constantes, num questionamento que desde o inícioprefigura uma pergunta à própria alma. O primeiro poema da série vemcom o 'enunciado': "Vida da minha alma: / Recaminhei casas epaisagens / Buscando-me a mim, minha tua cara.”, duas almas em um só corpo, "texturadas de mútua sedução" como canta no poemaLXVII, o qual também inicia interpelando a alma.

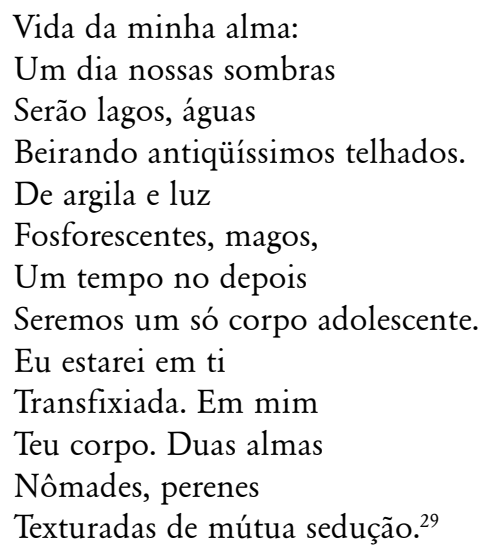

Voltamos à Sor Juana, que também ousa a poesia em transgressão.O trecho da epígrafe de Cantares de perda e predileção, retirado de Resposta a Sor Filotea, é um dos atos transgressores de Sor Juana em sua luta em versos pelo direito de conhecer, ou desejar saber. A Resposta é um escrito autobiográfico da monja em complemento à Carta Atenagórica(atenagórica significa: digna da sabedoria de Atena ${ }^{30}$ ), em que Juana Inés ousa criticar um dos sermões do Mandato do jesuíta português Antônio Vieira,no qual o padre exalta o amor de Cristo. AResposta foi motivada pela repercussão de sua crítica ao sermão de Vieira, que lhe rendeu ataques e intervenções de vários clérigos à sua condição de mulher e religiosa ${ }^{31}$.

Hilda Hilst recolhe fragmentos de textos em verso de Sor Juana e reúne tópos e fantasmas do barroco, no erotismo do coração em "líquido humor" desfeito nas mãos do amado e no inacessível objeto de desejo:

"... en líquido humor viste y tocaste / mi corazón deshecho entre sus manos".

Em oposição e espelho: o trabalho pelo desejo (inacessível) do saber.

"A mí, no el saber (que aún no sé) / solo el desear saber me hácustado gran trabajo".
29. Idem, Canto LXVII.

30.Não digno de nota, mas talvez de lembrança: o corvo de Poe pousa sobre um busto de Palas Atena. Transcrevo a última estrofe com a tradução de Haroldo de Campos que consta no ensaio publicado em 1971, Edgar Allan Poe: uma engenharia de avessos, p. 9: E o corvo, sem revoo, pára e pousa

No pálido busto de Palas, justo sobre meus umbrais;

E seus olhos têm o fogo de um demônio que repousa, E o lampião no soalho faz, torvo, a sombra onde ele jaz Ergue o voo - nunca mais!

31. Cf. PAZ, Octavio. Sor Juana Inés de La Cruz o Las Trampas de la Fe. México: Fondo de Cultura Económica, 1985, p. 534. 
32. AGAMBEN, Giorgio.

O Demônio Meridiano. In:

Estâncias, 2007, p. 32.

33.Idem, Sor Juana Ines de la

Cruz o LasTrampas de la Fé,

1985,p. 489.

34.CAMPOS, Haroldo.

Quatuor para Sor Juana. In:

Segundo Arco-íris branco, 2010, p. 48.
Hilda canta sua busca a si mesma, mais uma vez por umcaminho que a leva ao desejar saber de contornos eróticos, porque pensamento poético, na contracorrente deste gran trabajo que é avesso ao erotismo. Nesse caminho coabitam a disciplina ea paixão, o discursivo e a ciência, a voz e a linguagem, questões que perpassam as obrasde algumas das mulheres eleitas por Hilda para ocuparem um espaço em suabiblioteca de referências, como Sor Juana, Simone Weil, Edith Stein e Teresa D’Ávila.

Com o olhar atento, e pesquisa quase inesgotável, podemse vislumbrarsemelhanças e aproximações dos Cantares com o poema Primero Sueño. Em Cantares estão aalquimia, o ouro e a compaixão, as imagens transbordantes de signos, asfiguras geométricas, a água, o espelho, a barca, a faca, o silêncio, osanimais, cavalos-negros, tigres, leopardos, cadelas, enfim, são asmesmas referências imagéticas e simbólicas utilizadas como alegorias,rumo ao mesmo transcender que se encontra em Primero Sueño.A profusão das imagens em comum é evidente e forma uma rede intersubjetiva interessante por levarem aomesmo fim, em que,após viagem espiritual, o poeta chega ao mesmo lugar, o inapreensível de sua busca, numa espécie de exercício epifânico. Agamben alude a uma "epifania do inapreensível” relacionada à busca da sabedoria por parte do acidioso. Segue um trecho de $O$ Demônio Meridiano:

Ao mesmo tempo em que a sua tortuosa intenção abre espaço à epifania do inapreensível, o acidioso dá testemunho da obscura sabedoria segundo a qual só a quem já não tem esperança foi dada a esperança, e só a quem, de qualquer maneira, não poderá alcançá-las foram dadas metas a alcançar. ${ }^{32}$

No decorrer do poema Primero Sueño, de Sor Juana, também combatem opostos, comoa noite e o dia, o corpo e a alma, ointelecto e o entendimento, Razão e Fantasia."La fantasia iba copiando con sosiego "las imágenes todas de las cosas" y con su "pincel invisible" pintaba "las figuras mentales", "sin luz" y "con vistosos colores" 33 . Nos cantares de Hilda, hác"pincéis de fino pelo / Desenhando emoções.”Também em Sor Juana, no poema em que a poeta dorme o sono profundo e realiza sua viagem interior, prefigura-se a comunicação com sua alma, como em Cantares, de Hilda. Trata-se de uma pintura imaginária feita em poesia. Hilda Hilst e Sor Juana, a "poeta-pintora” na definição de Haroldo de Campos ${ }^{34}$, desenham imagens na alma e transferem-nas à linguagem poética de seus versos. Nesse momento, a distância se faz, entre conhecimento e desejo, razão e fantasia. Permanece o inapreensível e a imaginação. Aludindo às teorias de Platão no Filebo sobre "o artista que desenha na alma as imagens”, descreve Agamben: 
O tema central do Filebo não é, porém, o conhecimento, mas o prazer, e se Platão lembra ali o problema da memória e da fantasia, isso se deve ao fato de estar preocupado em demonstrar que o desejo e prazer não são possíveis sem essa "pintura na alma", e que não existe algo parecido com um desejo puramente corpóreo. Desde o início da nossa investigação, graças a uma intuição que antecipa de maneira singular a tese de Lacan, segundo a qual "Le phantasme fait le plaisir propre au désir", o fantasma situa-se, portanto, sob o signo do desejo, e este é um aspecto que não convém esquecer. ${ }^{35}$

Convém ainda lembrar que Hilda Hilst finaliza seus dez poemas da série Do Desejo, lançado em 1992 na coletânea homônima com o verso: "Pensá-LO é gozo. Então não sabes? INCORPÓREO É O DESEJO.”36

O silêncio é outro "lugar" onde se encontram as poetas na sua busca poética. Onde a voz silencia, no sonho da poeta mexicana, revelado desde o título Primero Sueño, Sor Juana encontra o “império silencioso". A poeta paulista alude à mesma ausência que é presença de um silêncio, quando revela o poeta-mudo que vigiando "as sonoridades dos avessos" faz-se esquecimento e emudece. O sonho da poeta Inés de La Cruz desenha as imagens da morte e do tempo, entre aavalanche de seres sublunares, as referência a Homero, as pirâmides, ascores, o azul e o ouro. Nas suas viagens, paira sempre o símbolorecorrente da circunferência, círculo e centro, temas recorrentes nos escritos de Hilda Hilst, independente do gênero em que se expressem.

Trata-se de um trabalho a ser feito, não agora, como simples apresentação de uma infinita e inútil profusão de imagens, mas futuramente, quando o tempo e o estofo teórico forem suficientes. No entanto, sirvo-me das palavras de Foucault para justificar essa análise (precipitada) como simples apreciação e tentativa de escuta de um mesmo núcleo de pensamentoque pode ser desvelado "nas dobras interiores à linguagem".

[...] parece-me que as possibilidades da linguagemem uma época dada não são tão numerosas que não se possam encontrar isomorfismos (portanto, possibilidades de ler vários textos em profundidade) e que não se deve deixar o quadro aberto para outros que ainda não escreveram ou outros que ainda não foram lidos. Pois tais isomorfismos não são "visões do mundo", sãodobras interiores da linguagem: as palavras pronunciadas, as frases escritas passam por eles, mesmo que eles acrescentem rugas particulares. $^{37}$

Frente à sua afeição investida de imagens da tradição lírica e trovadoresca, a poeta Hilda Hilst encena uma poesia barroca
35.Idem, O Demônio

Meridiano. In: Estâncias, 2007, p. 133.

36.HILST, Hilda. Do Desejo.

Poema X. 2004, p. 26.

37. FOUCAULT, Michel.

Distância, Aspecto, Origem, 2006, p.p. 61, 62 . 
38. AGAMBEN, Giorgio. O que é o contemporâneo? E outros ensaios. 2009, pp. 58, 59. e moderna quando revela a casa barroca no próprio corpo, o aniquilamento e o voo, ambos levando ao roteiro de um tempo que se esvai e ressurge, como dobras, elipses, centros múltiplos, descentrados, volantes. Como procedimento de desconexão, a linguagem evoca o erotismo, apresenta-se como voz a partir do corpo, embora represada no texto, restrita à palavra. Trata-se do erotismo do prazer do texto e do texto de fruição, nos quais se funda o abismo ou o contágio com o leitor. Mas também onde opera um potlatch quando se revelam dom e sacrifício numa lógica da perda, sem qualquer aplicação utilitária do ponto de vista econômico.

A poesia de H.H.é uma evocação da experiência do extremo, num lugar onde o mundo lógico, o mundo do discurso e dos dispositivos, o mundo da utilidade é substituído pelo fruir da experiência poética.As escritoras Hilda Hilst e Sor Juana, separadas pelo tempo e contexto, foramgeradas num mesmo e permanente clima de crise e colapso literário, são contemporâneas no distanciamento que se impuseram para que pudessem melhor enxergar o seu tempo e a partir daí formar suas próprias defesas aos dispositivos impostos pela verdade do cientificismo e pelas demais armadilhas do novo (ou de Deus) que se impunham sob a roupagem do moderno (ou da tradição).

O distanciamento, portanto, é uma atitude necessária para hoje olharmos um tempo passado e próximo do qual somos contemporâneos. Pois, segundo Agamben, o verdadeiramente contemporâneo não coincide exatamente com seu tempo, não está a ele adaptado, mas "exatamente através desse deslocamento e desse anacronismo, ele é capaz, mais do que os outros, de perceber e apreender o seu tempo." 38

No texto $O$ que é o contemporâneo?, Agamben inicia suas considerações intempestivas por meioda concepção do século sugerida poeticamente pelo russo Osip Mandelstam, num poema intitulado O século, de 1923. Na explanação de Agamben sobre o poema, exaltam-se as imagens que compõem o séculofera: o dorso quebrado do tempo e o sangue do poeta que sutura suas vértebras. Logo conclui Agamben que contemporâneo é aquele que se distancia justamente para manter o olhar fixo no obscuro do tempo, em suas trevas, não apenas para perceber o escuro do presente, mas também para perseguir uma luz que em meio às trevas procura, sem êxito, atingir o presente.

Sintomaticamente, Alain Badiou publica $O$ século,em 2005, antes de Agamben, a partir de seminários realizados entre 1998 e 2001 no Collège International de Philosophie, e faz longa referência ao mesmo poema de Mandelstam. Badiou alerta então para o século como besta, mas também alude ao sacrifício, à animalidade e ao valor orgânico do conhecimento. 
Ele assegura ainda que as duas vértebras quebradas do poema de Mandelstam representam dois séculos com suas diferentes, quase opostas, proposições. De um lado, os modelos mecânicos do cientificismo do século XIX, de outro, o valor orgânico das coisas como questão fundamental do século XX. No meio, a quebra e a tentativa de sutura pelo sangue. Para Badiou, o século XX é concernente "ao animal humano, como ser parcial transcendido pela Vida”.

Nessa inversão opera-se a transgressão da escrita de Hilda Hilst. Sua poesia responde em canto, com a voz suspensa no pensamento, o que se procura encontrar na linguagem.

VI

Tem nome veemente. O Nunca Mais tem fome.

De formosura, desgosto, ri.

E chora. Um tigre passeia o Nunca Mais.

Sobre as paredes do gozo. Um tigre te persegue.

E perseguido és novo, devastado e outro.

Pensas comicidade no que é breve: paixão?

Há de se diluir. Molhaduras, lençóis

E de fartar-se,

O nojo. Mas não. Atado à tua própria envoltura

Manchado de quimeras, passeias teu costado.

O Nunca Mais é a fera. ${ }^{39}$
39. HILST, Hilda. Cantares do sem nome e de partidas. In: Cantares. São Paulo: Globo, 2004. 


\section{Referências}

AGAMBEN, Giorgio. Estâncias: a palavra e o fantasma na cultura ocidental. Tradução de Selvino José Assmann. Belo Horizonte: Editora UFMG, 2007.

. O fim do pensamento. Tradução de Alberto

Pucheu. Disponível em : http://www.letras.ufrj.br/ciencialit/ terceiramargemonline/numero11/xii.html. Acesso em 20 de junho de 2013.

O que é o contemporâneo? E outros ensaios. Tradução de Vinícius NicastroHonesko. Chapecó: Argos, 2009.

BADIOU, Alain. O século. Tradução de Carlos Fenício da Silveira. Aparecida, SP: Ideias \& Letras, 2007.

BARTHES, Roland. O prazer do texto. Tradução de Maria Margarida Barahona. Lisboa: Edições 70, 1974.

BECKER, Ernest. A negação da morte. Tradução de Luiz Carlos do Nascimento Silva. Rio de Janeiro: Record, 1995.

BENJAMIN, Walter. A imagem de Proust. In: Magia e técnica, arte e política. Obras Escolhidas Vol.I. Tradução de Sérgio Paulo Rouanet. São Paulo: Brasiliense, 1994.

BÍBLIA de Estudos Dake. Cantares 1-8. Texto bíblico traduzido por João Ferreira de Almeida. Editora Atos, 2010, p. 1197-1205.

BROWN, Norman O. Vida contra Morte: O Sentido Psicanalítico da História. Tradução de Nathanael C. Caixeiro. Petrópolis: Vozes, 1974.

CADERNOS de Literatura Brasileira - Hilda Hilst, nª 8, out. - 1999. São Paulo: Instituto Moreira Salles, 1999.

CAMPOS, Haroldo de. Quotor para Sor Juana. In: $O$ segundo arco-íris branco. São Paulo: Iluminuras, 2010. Coloquio/Letras. Fundação Calouste

Gulbenkian. Cópia digital. Na3: Setembro 1971.

Disponível em: http://coloquio.gulbenkian.pt/bib/sirius. exe/issueContentDisplay? $\mathrm{n}=3 \& \mathrm{p}=5 \& \mathrm{o}=\mathrm{p}$. Acesso em $24 \mathrm{de}$ junho de 2013.

FOUCAULT, Michel. Distância, Aspecto, Origem. In:Estética: Literatura e Pintura, Música e Cinema. $2^{\circ}$ edição.Rio de Janeiro: Forense Universitária, 2006. 
HILST, Hilda. A obscena senhora D. São Paulo: MassaoOhno - RoswithaKempf Editores, 1982.

.Cantares de perda e predileção. São Paulo:

MassaoOhno - M. Lydia Pires e Albuquerque Editores, 1983. Cantares. Obras reunidas de Hilda Hilst. São

Paulo: Globo, 2004.

.Do Desejo. São Paulo: Globo, 2004.

PAZ, Octavio. Sor Juana Ines de la Cruz o LasTrampas de la Fé. 3o edição. México: Fondo de Cultura Económica, 1985.

POE, Edgar Allan. O Corvo, corvos e o outro corvo.

Organização e tradução de Vinícius Alves. Florianópolis:

Bernúncia, 2000.

SARDUY, Severo. Escritos sobre um cuerpo. In: Obra

Completa. Tomo II. Madrid: Scipione Cultural, 1999.

SCHETTINI, Ariel. Sor Juana Inés de la Cruz. Redondillas, El tesoro de la lengua, Buenos Aires: Entropía, 2009.

STERZI, Eduardo. Da voz à letra. ALEA: Rio de Janeiro. vol. 14/2 | p. 165-179 | jul-dez 2012.

ZAMBRANO, Maria. Dos fragmentos acerca del pensar. In: Orígenes - Revista de Arte y Literatura,Ano XIII, nª40, 1956, p. 5. 
